\title{
Hope, History and Redemption in the Theology of Richard Roberts (1874 -1945)
}

While World War I catalyzed the crisis of theological liberalism early in the twentieth century, the crisis had begun well before the summer of 1914. Both contemporary commentators and later historians have pointed to various factors precipitating this crisis, including the rise of secularization, the reassessment of earlier understandings of the relationships among theological, historical and scientific knowledge, and the consequent breakdown of certainty in religious truth, all of which were already apparent by the turn of the century. Nevertheless, World War I sharpened the crisis of theological liberalism, largely because of the shock to previously held convictions about the inevitability of progress and the perfectibility of humanity. In the years during and after the war, many pastors and theologians spoke of the "disintegration" or even the "death" of liberalism. Some looked to the emerging "neo-orthodox" theologies of Barth and Brunner in Europe and the Niebuhrs in North America for theological resources adequate to the crises of the time. Others worked to articulate a theology that retained what they regarded as liberalism's enduring strengths, both discarding the weaknesses of liberalism and rejecting what they regarded as the shortcomings of neo-orthodoxy. As John Bennett wrote in 1933, "Whatever the new theology may be which is to take the place of liberalism, of one thing I am sure: it will not be any of the other systems of theology which now have names." 2

One way in which some worked out their theological reassessments in these decades was through debates about the place of violence and non-violence in Christian life and the implications for theologies of hope, history and redemption. These debates intensified as Europe moved towards war again in the late 1930s. In its winter through summer issues of 1940, the American quarterly

michael bourgeois is Assistant Professor of Theology at Emmanuel College, Toronto, ON, Canada.

Toronto Journal of Theology 19/2, 2003, pp. 157-172 
Christianity and Society carried an illuminating exchange between Reinhold Niebuhr, then its editor, and Richard Roberts, a Welsh-born pastor and theologian who during World War I helped found the Fellowship of Reconciliation and, after immigrating to Canada in 1922, became the sixth moderator of The United Church of Canada from 1934 to 1936. At the time of his exchange with Niebuhr, the war in Europe had been underway for over a year. Germany had invaded Norway, Denmark, Belgium and the Netherlands and commenced its invasion of France. Against this background, the exchange between Niebuhr and Roberts reflects enduring issues in Christian debates about faithful means of resisting evil. It also illuminates some of the particular theological struggles in the first half of the twentieth century, and the ways in which those often polemical struggles shaped the theologies of hope, history and redemption of which we are the heirs. The theology of Richard Roberts also suggests that categories such as "liberal" and "neo-orthodox," as they have been typically used in theological dis course, are inadequate for describing the theological options available both in the decades immediately following World War I and today. It also suggests that his work and that of some of his contemporaries, theologians who were neither completely liberal nor fully neo-orthodox, may be worth recovering as resources for continuing constructive theological reflection on hope, history and redemption. $^{3}$

Born in northern Wales in 1874 and ordained in the Welsh Calvinist Methodist Church in 1897, Richard Roberts transferred to the Presbyterian Church of England in 1903. While minister at St. Paul's Church, London, he became acquainted with the Roman Catholic philosopher, Friedrich von Hügel, and shortly after he was called to Crouch Hill Presbyterian Church, London in 1910, he met the young John Macmurray. Over the next three decades, Roberts drew from a variety of sources in the development of his theological reflections. Although his interest in the natural sciences was not typical among Protestant theologians of his time, he can perhaps best be regarded as a late example of the evangelical approach to theology as a synthesis of various forms of knowledge, whether biblical, historical, philosophical, scientific, or literary. ${ }^{4}$ In addition to Niebuhr, Macmurray and von Higel, Roberts' theology was in conversation with such diverse thinkers as Augustine of Hippo, Samuel Alexander, William Blake, Henri Bergson, G.K. Chesterton, C.H. Dodd, Arthur Eddington, C. Lloyd Morgan and Alfred North Whitehead.

On the first Sunday after the outbreak of the "Great War" in August 1914, Roberts had prepared a sermon, "a potpourri of my own conflicting emotions," but did not deliver it for he realized during the service that the young German men who had been attending Crouch Hill were not in attendance. "I had a shattering intuition that perhaps my boys, the British and the German, might meet on some battlefield in Furope, where it would be their business to kill one another!" Rather than deliver his sermon, Roberts reported his realization and asked those present "to consider as Christians the appalling circumstance that lads of that congregation, who had worshipped God together in that church, 
might, under the orders of their superiors, be called to murder each other.... I knew when I left the church that morning that as a minister of Christ I could take no part in a war." ${ }^{5}$ Over the next several months, while most in the churches were engaged in what one contemporary described as "this Gadarene-swine race of the churches down a steep place into the sea," a few sought, in Roberts' words, "to do something to safeguard the Christian faith and testimony from being swamped by what seemed likely to be the greatest war in history." By the end of December 1914, Roberts, and Quakers Henry Hodgkin and Lucy Gardner, had established the Fellowship of Reconciliation. Roberts himself seems to have suggested the word "reconciliation," not only for the group's name but also as the task to which the members understood themselves committed. Through the fall of 1914, they came to see that "peace was something to be waged, as war was waged. Peace is not a passivity, a state or rest, a lull between wars. It must be conceived as an activity; and the name of that activity is Reconciliation, which is the finest of all arts, the art and practice of turning enemies into friends. It is the essential core of Christian divinity and of Christian ethics." Roberts' pacifism and other congregational tensions compelled him to resign his position at Crouch Hill in July 1915, whereupon he became Secretary of the F.O.R. and the first editor of its monthly journal, The Venturer. ${ }^{6}$

Roberts' writings from this period also reflect the formative influence of his anguish over the prospect of fellow Christians killing each other in the war. In a 1917 essay asking "Can a Christian Internationalism be Established?," he acknowledged both Christianity's failure to date to inculcate a bond stronger than that of nationalism, and the dreadful consequence of that failure in the war. Nevertheless, Roberts maintained that a Christian internationalism might yet be accomplished. He argued from the history of the malleability of national identities that more inclusive senses of human solidarity were possible. Further, while admitting that self-interest is "the regulative principle of the policies of all states," he maintained that such collective self-interest is neither inherent nor ineradicable.

There are those who tell us that nations cannot from the nature of the case act unselfishly... There is no reason why, if any group of people can act from unselfish motives, a nation should not likewise be able so to act. The national nexus is not in its nature essentially different from the social nexus which binds any group of people together; and to deny that groups of people can act Christianly is to decline into the kind of pessimism which summarily hands the world over to the devil. It is true, as any observer of human phenomena knows, that a group of people may in certain circumstances act collectively on a plane morally lower than any individual in the group would by himself be likely to do. But this is only one-half of an important truth. Groups may no less act collectively on a plane and reach a height far higher than would be possible to the individual. The sense of solidarity may reinforce the timid and wavering motives of individuals and enable them to act together with a force and a consistency which would otherwise be beyond their power. ${ }^{7}$ 
Roberts therefore urged the churches to "affirm that nationality does not rank as an ultimate principle for the determination of conduct" and to leaven the nations and lead them into the paths "of service, of goodwill, of faith" which "are also the paths of peace." 8

Roberts' work with the F.O.R. led him to ministry at the Church of the Pilgrims in Brooklyn, New York, where he was to advance the F.O.R. cause in the United States while working part-time at the church. After a trial period on contract there in 1916, he accepted a call and began a longer term appointment in January 1917, three months before the United States entered the war. After the war's end in 1918, he considered other employment options in both England and the United States, but nothing definite emerged until he was called to the American Presbyterian Church in Montreal in late 1921. With it he entered The United Church of Canada at its founding in 1925. In 1926, as a member of the Protes tant Ministerial Association in Montreal, he and several others published The Christian and War. Written by W.A. Gifford at the group's request, and by their own account reflecting the view of all of its members, The Christian and War demonstrated Roberts' own concerns for internationalism, conscientious objection and the active resolution of disputes and promotion of peace. Unlike some other contemporary pacifists, The Christian and War distinguished between war and international police actions and allowed that "there are circumstances in which force can be made to serve the ends of love, reverence and service." But because force "is such a servant as tends to break bounds and to seize control, to obscure the ends in view and substitute more immediate and lower ends," and its use already indicates a failure of one's responsibility or relationship, it may only be used rightly when exercised under the jurisdiction of an impartial and duly constituted authority. War, because it can never be subject to such controls on the use of force, can therefore never be justified. $^{9}$

In lectures and essays in the late 1920s, Roberts also sought to articulate a theology that held together the authentic points of the various dualities that, he observed, persisted throughout Christian history. Within this broader framework, he addressed questions of God and humanity, history and progress. ${ }^{10}$ Although he clearly believed that human and social progress was a possibility, he just as clearly rejected its inevitability. He criticized the churches' earlier "superstitious surrender to the Spencerian Doctrine of fate's progress,' which "the little thinking we have done since the war" had discredited. The "myth of a fated Progress" was clearly a failed prediction, however confidently it had been previously proclaimed in Western culture. ${ }^{11}$ The Christianity of that culture he regarded as little more than a religious egoism that was hopelessly inadequate to confront the dominant pagan egoism.

Its God had become contemptible. He was not the Alpha and Omega of life but a mere accessory to it: ancillary to the hopes and purposes of the individual.... But any sense of God as the inscrutable and transcendental end of life; any profound, creative, transfiguring conception of Him; any feeling of startled wonder and reverence in the presence of His handiwork and the vast processes of His Province was far to seek. ${ }^{12}$ 
Roberts outlined an alternative view of God, criticizing in particular Chris tianity's tendency to distort and misunderstand the universalism of the image of God as "Father" through its continuing reliance on images such as the "tribal God." Cautioning that we can never "reach a completely and permanently weather-proof conception of God within the conditions of terrestrial life," Roberts proposed a provisional conception of God as "universal, qualitative, social and organic." ${ }^{13}$ This view of God, especially its organic element, meant for Roberts that humanity can know the divine through those normal processes of life in which it is involved. "Properly understood," he argued, "everything that is, is a revelation of God." Because he explicitly included scientific knowledge of the universe and all within it in this view of revelation, and specifically sought to develop a theological understanding of evolution, Roberts looked to the history of life, particularly to the development of values in that history, for clues to an understanding of the nature of God. He argued that this history demonstrated the striving of matter and life for God and that this striving is continuous with human history, which is in itself a manifestation of God. In other words, the world's striving for God and God's reaching out to the world are a single process which we, because of our limitations, can yet see only as a duality. But Roberts did not claim that history offered a simple account of an uninterrupted progress. Indeed, he acknowledged that "at first sight the last thing that history suggests is that it is a manifestation of a God with whom we could care to have anything to do. It would be difficult to trace in it any orderly development, and that man-kind should have been capable of the Great War, after so long an experience of the self-defeating folly of war, is not reassuring evidence of a continuing evolution." Nevertheless, he maintained that "the history which is to show us the self-manifestation of God in a development which includes man, is the history that tells us how men acquired wisdom and knowledge, how they learnt to live with one another, how they grew to admire and to aspire towards goodness, truth and beauty. It is the history of man's discovery and culture of his spirit." 14

For Roberts the "most important episode" in this history is "the moral quality and achievement of Jesus," which manifests the nature of God not only in itself but also "in that which in ourselves endorses and endeavours to imitate it." In his account of the life, work and death of Jesus, Roberts emphasized that the rejection of Jesus and subsequent history show that "this world of violence and vice and vested interests is the world that is forever with us," but the cross of Jesus is yet a manifestation of God as a love that endures all. The nature of God is thusbest expressed as "love," which is also "the true 'human nature' not yet filly realized?' Perversions of life's striving such as "the lust for power, the arrogance of privilege, and self-indulgence" persist, and as do other manifestations of sin, understood as "a relapse to a lower condition than that to which we had reached or may attain." Nevertheless, "despite all these perversions of life which make for death, life is struggling to the realization of itself in perfect love?' Jesus, then, reveals not only God's nature but also humanity's future. In the experiences 
which we describe variously as conversion, transformation, regeneration, or sanctification, the divine spirit in Jesus works also in humans for their transformation and the creation of the Beloved Community. "In Jesus, manhood is joined to Deity; and in Him God was starting a new race." 15

In 1927, Roberts moved to Sherbourne United Church in Toronto, where he remained until 1938; during this time, from 1934 to 1936, he also served as the United Church's sixth moderator. By the late 1930s he was a well-known and well-respected leader of the church, factors which were likely significant for his role in the "Witness against War" controversy in October 1939. In Halifax, lecturing at Pine Hill Divinity School at the time, Roberts had been in correspondence with Edis Fairbairn, the main organizer of the "Witness," and had agreed to add his name to a public declaration against war. Roberts had nevertheless counselled against a declaration because he regarded 1938 United Church statements on war to be "so great an advance on any comparable document in 1914." ${ }^{16}$ As the war approached in 1939, however, the attitude in the United Church began to shift towards support for Canadian involvement. When the "Witness against War" appeared shortly after Canada's declaration of war, including among its seventy-five signatures that of Richard Roberts, a controversy in both state and church ensued. The Ontario attorney general considered legal action against those who had signed the "Witness;" but ultimately took none. A statement by the United Church's General Council sub-executive attempted to achieve a mediating position but succeeded in pleasing few. Although they faced no official sanction, many of those who signed the "Witness against War" faced further conflict in their congregations and some were compelled to leave their positions." 17

In Halifax, Richard Roberts felt that the controversy in Ontario had justified his concern about the inadvisability of a public statement at that time. He regarded the action of the United Church's sub-executive as "feeble and cowardly," however, particularly in its failure to affirm the right of the church's "ministers to hold and express dissenting convictions." He was "rather grateful in some ways that my name is on the list," but his gratitude was tempered by repentance. Although he was strongly anti-fascist, Roberts remained anti-war. In the spring of 1940, he wrote to one of his daughters: "As to the war business as a whole-I am pretty much where I was ... but with difficulty. Both sentiment and judgment make me very partisan - as between the combatants - the ethical disparity of the two sides is hardly measurable. But I am sure that the Church should stick to its own job-if everything is not to go with the flood." Roberts was equally sure, however, that neither the church nor pacifism had done their jobs during the preceding twenty years. The war indicated for him "the actual and tragic failure of pacifism" and suggested that "the proper wear of pacifists at this time is sackcloth and ashes. Personally, I feel under conviction in the matter very keenly." ${ }^{18}$ Roberts' sense of the tragic failure of pacifism, however, did not prevent him from responding to Reinhold Niebuhr's 1940 critique of Chris tian pacifists. 
In the early 1930s Niebuhr had helped to form the Fellowship of Christian Socialists and had publicly departed from the Fellowship of Reconciliation and his own previously held pacifist convictions. In 1932, Niebuhr also published his book Moral Man and Immoral Society, in which he argued against the prevailing Christian liberalism that "a sharp distinction must be drawn between the moral and social behaviour of individuals and of social groups, national, racial and economic; and that this distinction justifies and necessitates political policies which a purely individualistic ethic must always find embarrassing." ${ }^{19}$ While he acknowledged that it is possible "to establish just relations between individuals within a group purely by moral and rational suasions and accommodation, ${ }^{20}$ Niebuhr concluded:

In inter-group relations this is practically an impossibility. The relations between groups must therefore always be predominantly political rather than ethical, that is, they will be determined by the proportion of power which each group possesses at least as much as by any rational and moral appraisal of the comparative needs and claims of each group. The coercive factors, in distinction to the more purely moral and rational factors, in political relations can never be sharply differentiated and defined. ${ }^{21}$

Niebuhr's turn from pacifism was directly related to his socialism, and his departure from the F.O.R. was one outcome of the controversy that had arisen within it over the use of violence to resist capitalism. By 1933, while the overwhelming majority of F.O.R. members remained committed to nonviolence in conflicts between classes as well as nations, a vocal minority, including Niebuhr, had come to believe that violent resistance to economic oppression was justifiable, if not necessary, to bring about a more just social and economic order. This minority also included F.O.R. Executive Secretary Joseph Matthews, who was dismissed by the F.O.R. council near the end of 1933. Niebuhr announced and explained his own departure in his January 1934 essay, "Why I Leave the F.O.R.," but did not completely repudiate the role of pacifism in the establishment of justice.

Recognizing, as liberal Christianity does not, that the world of politics is full of demonic forces, we have chosen on the whole to support the devil of vengeance against the devil of hypocrisy. In the day in which we live, a dying social system commits the hypocrisy of hiding its injustices behind the forms of justice, and the victims of injustice express their politics in terms of resentment against this injustice. As Marxians we support this resentment against the hypocrisy. As Christians we know that there is a devil in the spirit of vengeance as well as in the spirit of hypocrisy. For that reason we respect those who try to have no traffic with devils at all. We cannot follow them because we believe that consistency would demand flight to the monastery if all the devils of man's collective life were to be avoided. But our traffic with devils may lead to corruption, and the day may come when we will be grateful for those who try to restrain all demons rather than choose between them. ${ }^{22}$ 
In 1935, Niebuhr became editor of Radical Religion. In its early years the journal focussed on considering strategies for social reconstruction in a way that might elicit Christian support for socialism. But as the reformed capitalism of the New Deal took hold in the United States, Stalin executed his purge in the Soviet Union, and fascism gained strength in Germany, Italy and Spain, Niebuhr and Radical Religion began to emphasize the need to support democracy and resist fascism, even by the use of force. By 1940, Niebuhr was demonstrating little of the respect for "those who try to have no traffic with devils at all" that he had professed just a few years earlier. In a 1940 essay, "Christian Moralism and War," he criticized proponents of a perfectionist Christian moralism that was "little more than eighteenth-century rationalism and optimism, compounded with a little perfectionism, derived from the sanctificationist illusions of sectarian Christianity." In their simple equation of American neutrality with the Sermon on the Mount, such moralists were, in his view, "evading the judgment of God which stands equally over every nation" and "escaping the important duty of making relative distinctions between good and evil, between truth and falsehood, between freedom and tyranny?' By making such relative distinctions we should not, Niebuhr cautioned, "imagine that we are the righteous who must destroy the sinners?' Nevertheless, he insisted that we remain responsible for "securing such justice as is possible through resisting flagrant injustice and tyranny" even though it requires "setting sin against sin." Such a course was justified because "all life is involved in a contradiction to the will of God" and "every man stands under judgment because every man is involved in contradicting the law of Christ?' Niebuhr did allow that it was possible for some to "symbolize the more excellent way" but argued that this could be no substitute for political strategy. Further, he suggested that the modern pacifist usually also "detracts from the splendour of his moral example by self-righteous preachments." 23

Roberts was apparently genuinely pained by Niebuhr's essay, both because of what he said and because it was Niebuhr who had said it. In his "Open Letter" (published after Radical Religion had changed its name to Christianity and Society), he chided Niebuhr for accusing pacifists of selfrighteousness. Not only did Niebuhr's charge reflect the same tendency in himself, Roberts pointed out, but his use of "ill-natured words" suggested that Niebuhr sensed the weakness of his own argument. Roberts conceded that "you can find all sorts of faults and perversities in the pacifist movement" but suggested to Niebuhr that there was "at least the same proportion of sentimentalists on your side of the fence?' Returning to the same personal note with which he had begun it, Roberts continued in his reply: "It hurts me, though, to see your flag at half-mast, when I remember how bravely it once bore 'the battle and the breeze.'... [Y] ou have followed your own convictions. But, my dear Niebuhr, will you not think it over again?" To encourage this rethinking, Roberts argued with Niebuhr on three issues: first, the relevant moral judgments about war; second, the relation of the absolute and the ideal in Christian moral life; and third, the relation of his - 
tory to the incarnation of God in Jesus Christ and the process of redemption of which it is a part. ${ }^{24}$

Although during World War I Roberts and other pacifists had sometimes argued that neither side in that or any war held the moral high ground, in 1940 Roberts not only morally differentiated between the combatants, as Niebuhr had complained pacifists did not, but also acknowledged that "in every war, one side is more in the wrong than the other." Roberts agreed with Niebuhr's moral judgment about the combatants, saying "I detest Hitlerism and all its works." He also agreed that in "certain circumstances and under certain conditions, it may be a duty to use force." But he pointed out that the moral differentiation of the combatants was not the only differentiation required, for one must also distinguish between the "use of force" and the "process of war." The process of war was of such a qualitatively different moral character that it "must not be lumpedup and discussed in the abstract as a 'use of forced'" Because "murder and mendacity" are central to the conduct of war, Roberts argued, war is "a plain negation of that Righteousness of God which is the beginning and the end of the Christian Gospel of Redemption" and "as cate ${ }^{\mathrm{g}}$ orical a denial as it is possible to conceive of 'the grace and truth that came by Jesus Christ." To Niebuhr he therefore observed: "It does seem to me that you are deserting the moral realism which I have always associated with you, when you hold, as you apparently do, that there can be so much moral difference between the two parties to a war as to make participation in a policy of murder and mendacity justifiable."25 Roberts also argued that given the tendency of war to perpetuate itself and its evils, one ought not to be confident of its use in resisting evil and establishing relative justice.

On the relation of the absolute and the relative in Christian moral life, Roberts argued that the choice facing Christians was not between what Niebuhr called "simple Christian moralism" and Niebuhr's own approach, described in his own words as "the effort to construct such relative justice as is possible within the limits of human selfishness." For Roberts, Niebuhr's approach was an "equally simple moral relativism ... which seems to me to be the last term of 'liberalism' Certainly, it is not 'radical religion.' I should describe it as 'middle of the road religion'" Roberts maintained therefore that for "Christian folk, the Person, the Life and Death of Jesus Christ must be regulative of their life and thought, and absolute for their faith." Despite the unattainability of the ideal, he asked, "am I, on that account, to justify a relative following of Christ and settle down complacently to it?" Failure to attain the ideal "does not entitle me to make a virtue or a sort of philosophy out of my failures - which is just what this 'moral rela tivity' business does." Roberts also worried that Niebuhr's approach might be "the first step down a very slippery slope,' especially for those who were not, as he acknowledged Niebuhr was, "conscious of the inner tension between the relative and the ideal?' He argued then that it was the business of the church's min isters not to advocate the relative over the absolute, but rather "to keep alive the 
tension" between the absolute and the relative; not to "make war righteous (more or less) for one party in the quarrel?' but rather "to proclaim the righteousness of God as it is disclosed in Jesus Christ and Him Crucified."26

The incarnation of God in Jesus Christ was also for Roberts central to understanding history and what might be possible within it. While Niebuhr argued that "the human situation remains the same in peace and in war, though it may be more clearly seen in war than in peace, ${ }^{127}$ Roberts maintained on the contrary:

War is an incident in the course of a world which God sent His Son to redeem. And why should any incident in history be allowed to impose a moratorium on the business of human redemption? Am I to soft-pedal the Incarnation of God in Jesus Christ at every international crisis? The episode that we call the Incarnation should have a certain absolute significance for Christian believers-it is the only passage of history that has that character: and it is our one hope over against our desperate plight in this world. ${ }^{28}$

Implicit in Roberts' understanding of the relation of history and the incarnation is his conviction that the power of the spirit of God in Jesus Christ can and does operate to regenerate persons. By repentance, conversion and transformation, humans can be recreated and sanctified for the redemption of all that can only come with the establishment, by the world striving for God and God reaching toward the world, of God's righteousness.

Niebuhr responded to Roberts in the next issue of Christianity and Society and conceded that Roberts may have been correct in warning him about accusing pacifists of self-righteousness. Niebuhr also acknowledged that, although he could find little of it, "[t]here is a type of Christian pacifism which does not rest upon illusions about the goodness of man" and that Roberts was of that type. And he further admitted the validity of Roberts' cautions about the danger of moral relativism, agreeing that it "easily degenerates into opportunism, and opportunism into unprincipled conduct," and his affirmation that Christians must maintain the tension between the absolute and the relative. But Niebuhr insisted, and charged that Roberts did not recognize, that Christians must also "preserve some rela tive decency and justice in society against the tyranny and injustice into which society may fall," and that doing so requires "supporting relative standards of justice against the threats of anarchy and injustice." Specifically, Niebuhr charged Roberts: "You are willing to slightly favor the Allies against Hitler, but you are not willing to allow such a discrimination to result in an action in favor of one side against the other....Your difficulty is that you want to try to live in history without sinning.,"29

Although he thus seems to have misunderstood Roberts' view of how Chris tians are to act in the tension of the relative and the absolute, and although he ignored Roberts' insistence that war is of qualitatively different moral character than other means for preserving relative goods, Niebuhr nevertheless clearly grasped and ably articulated the fundamental difference between his own view and the view of those he opposed -- or at least, his characterization of the view 
of those he opposed. Specifically citing Roberts' question about war, history and redemption, Niebuhr observed:

Fully analyzed the question reveals the theological gulf between pacifism and nonpacifist Christianity. I do not believe that war is merely an "incident" in history but is a final revelation of the very character of human history. I do not believe that we ought to "soft-pedal the Incarnation at every international crisis." I believe that an international crisis merely reveals in its most vivid form what human history is like and I accuse pacifists of not being aware of its character until it is thus vividly revealed.... I do not believe that the Incarnation is "redemption" from history as conflict. Since I believe that sinful egoism expresses itself on every level of moral and spiritual achievement and is not absent from the highest levels of Christian life, I cannot regard redemption as freedom from sin. The redemption of Christ is rather the revelation of a divine mercy which alone is able to overcome the contradictions of human history from which even the best of us cannot extricate ourselves.... I take the Reformation doctrine of "justification by faith" seriously and I observe that the spiritual ground upon which our modern pacifism has grown is a sectarian perfectionism which hasn't the slightest idea of what the Reformation meant by its doctrine of "justification by faith." In terms of theological history our modern Protestant perfectionism is more deeply engulfed in illusions about human nature than the Catholic pretensions of perfection, against which the Reformation was a protest. In its most consistent form Reformation Christianity is inclined to substitute the concept -Christus pro nobis" completely for the idea of "Christus in nobis" and thus to deny any possibility of making Christ the norm of our life. This is an error. But it is no greater error than that which is committed by both Catholic and sectarian perfectionism which believes that divine grace actually lifts man out of the sinful contradictions of history and establishes him above the sins of the world. ${ }^{30}$

There is no record of any response to Niebuhr by Roberts.

From the summer of 1940, Roberts lived in the United States, preaching, leading retreats and addressing student conferences there and in Canada. In the fall of 1944, his health began to deteriorate due to arteriosclerosis and resulting strokes. He died in a nursing home in Brooklyn on April 10, 1945, less than a month before the end of the war in Europe. ${ }^{31}$

However ably Niebuhr stated the faults of modern sectarian perfectionist pacifism and the liberalism of which it was a part, it is not at all obvious that Richard Roberts shared them or that liberalism and neo-orthodoxy were the only available theological options. The critique of liberalism and the reconstruction of Christian theology undertaken in the wake of World War I included the efforts of theologians like Roberts who neither clung to the discredited elements of liberalism nor accepted all of the claims of the emerging "crisis" or "neo-orthodox" theologies. Douglas John Hall notes that Christian liberalism "was and (where it still exists) is neither monolithic nor uniform.... Like most other such categories (evangelicalism, for instance), liberalism covers a spectrum." Of course Hall, too, maintains that "with the possible exception of the 
Social Gospel, Christian liberalism wished to make itself amenable to what was, after all, an exceptionally expectant image of human being and society; therefore it tended to soften, if not altogether to dispense with, all those aspects of traditional Chris tian doctrine that came into conflict with such a conception of human nature and destiny?' As a result, Christian liberalism "became so enmeshed in illusion that it was incapable of responding to the reality of war when it actually occurred" and "had little or nothing left with which to comprehend the material and spiritual devastations laid open by the war, let alone with which to comfort its myriad victims." ${ }^{32}$

But were all those who dissented from the emerging neo-orthodox theologies liberals whose "unconditionally positive expectations" had made them unable to respond either to the victims or to the theological implications of the war? Should the theology of Richard Roberts be regarded as an example of a dis credited liberalism that leaves Christians ill-equipped to contend with the depths of evil and the tragedy of history? Does the standard typology of liberal and neoorthodox theologies adequately describe actual theological positions in the 1930s, or might Richard Roberts represent an alternative that has not been fairly considered on its own terms? Are liberalism's optimism about inevitable progress and neo-orthodoxy's realism about evil in human nature and history the only options for understanding hope and redemption and their role in history?

Niebuhr's specific depiction of Roberts' view is inaccurate on some key points in ways that are important for clarifying Christian understandings of redemption and their import for our moral evaluation of violence as a means to resist evil. Roberts clearly did not endorse war as an action of the Allies against Hitler, but he nowhere denied the legitimacy of resisting tyranny and injustice by resort to relative standards of justice, and never suggested that the business of Christians was to live in history without sinning. While Roberts failed to propose an alternative to war that would have satisfied Niebuhr's concern to defend "a decent scheme of justice" from "the real peril of tyranny," Niebuhr similarly failed to respond to Roberts' contention that war as a strategy for resisting evil is qualitatively different from other strategies and cannot be simply treated as one relative good among others. In his response to Roberts, Niebuhr insisted that [e]very form of Christian righteousness which rests upon a too simple doctrine of redemption must degenerate into a selfrighteousness in which the 'man in Christ' looks with scorn and judgment upon the man who is presumably not in Christ," ${ }^{33}$ but his preoccupation with the selfrighteousness of the perfectionist seems to have made it difficult for him recognize that a doctrine of redemption not as exclusively focussed on justification as his own might in fact be able both to avoid the self-righteousness he so loathed and to account for the regeneration of persons for moral action that more closely approximates the absolute.

Although Niebuhr acknowledged that it was as erroneous to focus one-sidedly on Christus pro nobis as on Christus in nobis, on justification as on sanctification, he failed to recognize that balancing these dual aspects of Christian witness might be both possible and legitimate. In his anti-pacifist polemic, 
Niebuhr elevated what he characterized as Reformation Christianity above both Catholic and Protestant "perfectionisms" and represented them exclusively in terms of a decadent medieval works righteousness and a deluded modern progressivism. Christians like Roberts who have stressed redemption as sanctification have not all maintained, as Niebuhr would have it, that "divine grace actually lifts man out of the sinful contradictions of history and establishes him above the sins of the world," but rather that divine grace not only forgives but also regenerates and transforms people in history while they work to overcome their own sins and the sins of the world. Niebuhr may have been correct that many or even most pacifists in the 1930s and 1940s did not have "the slightest idea of what the Reformation meant by its doctrine of 'justification by faith.'" But in his argument against pacifism, Niebuhr himself failed to demonstrate either an appreciation for sanctification as a genuine, enduring element in the Christian understanding of redemption, or an understanding of the reality of the transforming power of God in people's lives. The Reformation doctrine of justification by faith is surely necessary, particularly when it must correct excessive optimism about the realization of God's love in history; but it is not sufficient, particularly when emphasizing justification by faith undermines warranted hope for and action toward partial realizations of God's love in history. ${ }^{34}$

Roberts also clearly shared some of the key elements of the neo-orthodox theological program. Unlike the liberals of his time, he was, as Niebuhr acknowledged, "quite conscious of the persistence of $\sin$ in life." He rejected the inevitability of progress and other liberal ideas of God and human abilities that prevailed in Europe prior to the "Great War." He did not agree with the liberal view that "divine grace actually lifts man out of the sinful contradictions of history" or that "redemption is freedom from sin?' Roberts differed from both neo-orthodoxy and liberalism, however, in his attempt to balance, even if only in a provisional way, the dual elements of Christian experience and witness that neo-orthodoxy and liberalism tended to exclusively emphasize: God's transcendence and God's immanence; Jesus' divinity and Jesus' humanity; redemption as justification and redemption as sanctification; humanity as sinful; and humanity as sharing in the life of the divine. Roberts' insistence on the reconciliation of dualities, especially his sense of the ultimate unity of the process of the world striving for God and God reaching toward the world, also entailed rejecting the impasse between the coming of the Reign of God by human action or by divine action, between having to choose between redemption within history and redemption beyond history. Rather, Roberts affirmed that divine grace enables people to live faithfully in history's sinful contradictions and that redemption entails both forgiveness of sin and power over it.

Whatever our understanding of the role of force, violence, or war to resist evil and establish some measure of justice, we must surely avoid a one-sided emphasis on the possibility of sinlessness and consequent reliance on redemption as regeneration. We must surely also avoid an equally one-sided emphasis on the inevitability of sin and the consequent near-exclusive reliance on redemption as 
forgiveness. In the context of the struggle against fascism at mid-century, Niebuhr's "Christian realism" certainly provided a constructive framework for conscientious Christian action, particularly as an alternative to approaches that identified neutrality in the face of fascism with the Sermon on the Mount. Duing World War II, Niebuhr himself certainly worked to maintain the tension between the absolute and the relative, to hold the conduct of the war up for moral judgment, and to affirm the sense of the war not as a righteous cause but as a tragic necessity to preserve relative justice. Taken alone and out of context, however, "Christian realism" too readily obscures the need for the active pro motion of peace and, at least in the decades since World War II, has too readily justified the use of coercion and violence and too happily wedded Christianity to capitalism in ways that almost certainly would have made Niebuhr uncomfortable." Further, Niebuhr's anti-pacifist, anti-utopian rhetoric does not provide a complete account of the theological resources available to Christians who struggle with the role of violence in resisting evil and fostering hope. The Christian reconciliation of Richard Roberts, and the theological understanding of hope, history and redemption that are its correlates, are necessary elements of a more complete account of available Christian theological resources. In this, at least, Niebuhr may have been right. In light of the religious justifications of oppression and war over the past sixty five years, we might now paraphrase him and say that our traffic with devils has led to corruption, and the day may have come when we are grateful for those like Richard Roberts who tried to restrain all demons rather than choose between them,

\section{Notes}

1 John Bennett, "After Liberalism-What?" Christian Century, 50, 45 (8 November 1933): 1403-1406; Michael Gauvreau, The Evangelical Century: College and Creed in English Canada from the Great Revival to the Great Depression (Montreal \& Kingston: McGill-Queen's University Press, 1991), pp. 255-291: David B, Marshall, Secularizing the Faith: Canadian Protestant Clergy and the Crisis of Belief 1850-1940 (Toronto: University of Toronto Press, 1992), pp.156248; and D ouglas John Hall, "'The Great War' and the Theologians," and Donald Schweitzer, "The Great Depression: The Response of North American Theologians" in The Twentieth Century: A Theological Overview edited by Gregory Baum (Maryknoll, NY, London, and Toronto: Orbis Books, Geoffrey Chapman, and Novalis, 1999), pp. 3-13; 49-60.

2 Bennett, "After Liberalism - What?" p. 1403.

3 Reinhold Niebuhr, "Christian Moralism in America," Radical Religion, 5 (Winter 1940): 1620; Richard Roberts, "O pen Letter from Dr, Richard Roberts:' Christianity and Society 5 (Spring 1940): 41-43; and Reinhold Niebuhr, "An Open Letter to Richard Roberts," Christianity and Society, 5 (Summer 1940): 30-33, reprinted as "An Open Letter (to Richard Roberts)," in Love and Justice: Selections from the Shorter Writings of' Reinhold Niebuhr edited by B.D. Robertson (Cleveland and New York: Meridian Books. 1967), pp. 267-271.

$4 \mathrm{G}$ auvreau, The Evangelical Century pp, 284-291.

5 Richard Roberts, "How the Fellowship Began," Fellowship, 9 (January 1943): 3, also found in Box 4, File 98, Richard Roberts Papers, The United Church of Canada/Victoria University Archives; and Gwen R.P. Norman, Grace Unfailing: The Radical Mind and the Beloved Community of Richard Roberts (Etobicoke, ON: United Church Publishing House, 1998), pp. 83, 271. 
6 Roberts, "How the Fellowship Began," 5; Thomas P. Socknat, Witness against War: Pacifism in Canada, 1900-1945 (Toronto: University of Toronto Press, 1987), p. 100; and Peter Brock and Nigel Young, Pacifism in the Twentieth Century (Syracuse and Toronto: Syracuse University Press and University of Toronto Press, 1999), pp. 23-24.

7 Roberts, "Can a Christian Internationalism be Established?" in Norman Thomas et al,, The Conquest of War: Some Studies in the Search for a Christian World Order (New York: Fellowship Press, 1917), pp. 37-38.

8 Ibid., pp. 39-40.

9 The Christian and War (An Appeal) (Toronto: McClelland \& Stewart, 1926). pp. 90-93; and Socknat, Witness against War, pp. 101-105. In addition to Roberts and Gifford, the group included M.F. McCutcheon, Allan P. Shatford, W.D. Reid, and T.W . Jones.

10 "The Theological Dilemma in America," The Hibbert Journal, 25 (O ctober 1926-July 1927): 140-141; The New Man and the Divine Society (New York: Macmillan. 1926); The Christian God (New Y ork: Macmillan, 1929); "The Scope of Theology," unpublished lectures, 1927, Box 4. File 112, Richard Roberts Papers, United Church of Canada/ Victoria University Archives; "Wheels and Systems: A Plea for Another Theology," unpublished manuscript, Box 3, File 17, Richard Roberts Papers, United Church of Canada/ Victoria University Archives; Catherine Gidney, "Richard Roberts: A Case Study in Liberal Protestantism in Canada D uring the Interwar Years," in Historical Papers 1995: Canadian Society of Church History, edited by Bruce L. Guenther (Annual Conference, Université du Quebec a Montreal, 9-10 June 1995), pp. 81-100, a version of which appears as "Contextualizing Richard Roberts' Thought: Liberal Prote stantism and the Dilemmas of the Modern Age," in Norman, Grace Unfailing, pp. 263-286.

11 Roberts, "The Scope of Theology," p. 48, and The New Man and the Divine Society, pp. 9-10, 40.

12 Roberts, "The Scope of Theology," pp. 20-21.

13 Ibid., pp. 23-25.

14 Ibid., pp. 13-27.

15 References in this paragraph are to be found in ibid., pp. 36-39, 48-60, See also, Roberts, "The Theological Dilemma in America." p. 147.

16 "'Witness against War' Papers," Box 3, File 64, Richard Roberts Papers, United Church/ Victoria University Archives.

17 "'Witness against War' Correspondence," Box 2, File 50, Richard Roberts Papers, United Church/Victoria University Archives; United Church Observer, 15 O ctober 1939, p, 21, See also, Norman, Grace Unfailing, pp. 241-245; and So cknat, Witness against War, pp. 200-211.

18 "'Witness against War' Papers," Box 3, File 64, Richard Roberts Papers, United Church/ Victoria University Archives.

19 Brock and Young, Pacifism in the Twentieth Century, pp. 137-139; and Charles C. Brown, Niebuhr and His Age: Reinhold Niebuhr's Prophetic Role in the Twentieth Century (Philadelphia: Trinity Press International, 1992), pp. 56-59.

20 Reinhold Niebuhr, Moral Man and Immoral Society (New York: Charles Scribner's, 1932; reprint ed., 1960), pp, xi-xii, xxiii-xxiv.

21 Ibid.

22 References in this paragraph to Reinhold Niebuhr, "Why I Leave the F.O.R.," Christian Century (3 January 1934): 17-19, reprinted in Robertson, ed., Love and Justice, pp. 254-259; Brock and Young, Pacifism in the Twentieth Century, Niebuhr and His Age, pp. 138-142; and Brown, Niebuhr and His Age, p. 53.

23 References in this paragraph to: Niebuhr, "Christian Moralism in America," pp. 16-20; Brock and Young, Pacifism in the Twentieth Century, pp. 137-139; Brown, Niebuhr and His Age, pp. 5659; and John Bennett, "Reinhold Niebuhr's Social Ethics," in Reinhold Niebuhr: His Religious, Social, and Political Thought, edited by Charles W. Kegley and Robert W. Bretall (New York: Macmillan, 1956), pp. 64-68.

24 References to Roberts, "O pen Letter from Dr, Richard Roberts," pp. 41, 43.

25 Ibid., pp. 41-43. 
26 References in this paragraph in ibid., pp. 41-42,

27 Niebuhr, "Christian Moralism in America," p. 18.

28 Ibid., p. 42.

29 All references in this paragraph in Niebuhr. "An Open Letter to Richard Roberts," pp. 30-31.

30 Ibid., pp. 30-33; Bennett, "Reinhold Niebuhr's Social Ethics," pp. 68-71; and Socknat,

$W$ itness against $W$ ar, pp. 223-224.

31 Norman, G raœU nfailing, pp. 251-258.

32 All references in paragraph in Hall. "The Great War' and the Theologians." p. 8.

33 Niebuhr, "An Open Letter to Richard Roberts," p. 31.

34 For references in paragraph, see D onald Schweitzer, "The Great Depression," in Baum,

The Twentieth C entury, p. 58; D aniel D ay Williams, "Niebuhr and Liberalism"; William

John Wolf "Reinhold Niebuhr's Doctrine of Man"; and Paul Lehmann, "The

Christology of Reinhold Niebuhr," in Kegley and Bretall, Reinhold N iebuhr, pp. 205-209, 237-249, and 252-280 respectively,

35 For references above, see Brock and Young, Pacifism in the Twentieth C entury, pp. 140-142; Hall, "The Great War' and the Theologians," in Baum, ed., The Twentieth Century: A Theological 0 verview, pp. 10-11; and Beverly W. Harrison, "The Role of Social Theory in Religious Social Ethics: Re-examining the Case for Marxian Political Economy," Making the C onnections: E ssays in F eminist Social E thics, edited by Carol S. Robb (Boston: Beacon Press, 1985), pp. 58-63. 